Proc. Estonian Acad. Sci. Biol. Ecol., 2006, 55, 1, 31-50

\title{
Nest-tree and nest-stand characteristics of forest-dwelling raptors in east-central Estonia: implications for forest management and conservation
}

\begin{abstract}
Asko Lõhmus
Institute of Zoology and Hydrobiology, Centre of Basic and Applied Ecology, University of Tartu, Vanemuise 46, 51014 Tartu, Estonia; Asko.Lohmus@ut.ee

Received 16 February 2005

Abstract. I studied 423 nests of six raptor species in east-central Estonia to (1) distinguish the essential features of the nest sites, (2) link the nest-tree and nest-stand characteristics, and (3) explore whether the availability of potential nest trees and stands limits raptor populations in managed forest landscapes. Aquila pomarina was the only species having distinct preferences for a few site types, while Accipiter gentilis and Falco subbuteo selected stands according to composition rather than site type. Coniferous trees, particularly spruce, were greatly favoured for nest-building by all species, probably due to better protective cover. Size of the nest tree was more important than its age; though on poor soils, nest trees were both older and smaller. A. gentilis, A. pomarina, and Buteo buteo appeared to be most prone to the lack of potential nest trees in managed forests, e.g. stands $<80$ years old were generally inhabitable only if these contained older trees. Green-tree retention could greatly add nest sites for these raptors in managed forests. However, nest-site selectivity did not correlate with the population sizes of the six species, suggesting that nest-sites were not the main limiting factor for them.
\end{abstract}

Key words: forest birds, habitat selection, hemiboreal forest, retention trees, silviculture.

\section{INTRODUCTION}

The majority of diurnal raptor species (Aves: Accipitriformes et Falconiformes) nest in woodland (Del Hoyo et al., 1994), and many species suffer from the impacts of modern forestry (e.g. Jullien \& Thiollay, 1996; Fuller, 1996; Kontkanen et al., 2004). Though this is increasingly taken into account in forestry planning (e.g. Reynolds et al., 1992; Petty, 1998; Kontkanen et al., 2004), many gaps of 
knowledge should be still filled for effective prescriptions (Niemi \& Hanowski, 1997). Notably, (1) the relative importance of and trade-offs between habitat features should be better understood (Lõhmus, 2004a) and (2) regional case studies on critical nest-site characteristics should be carried out, given the geographical variation in raptors' requirements and in forest composition and structure (Penteriani, 2002; Väli et al., 2004).

In even-aged silviculture, such as in northern Europe, the basic management unit is a forest stand - a distinct part of forest, usually delineated according to tree-growth conditions (site type), and age and composition of the tree layer. In contrast, temperate and boreal forest raptors depend primarily on potential nest trees - larger species require old, huge, often malformed trees with strong branches (e.g. Tjernberg, 1983; Saurola, 1997; Bergmanis, 2004; Bielánski, 2004). Hence, for effective conservation management, it is crucial to connect the two scales - to understand which stands contain suitable trees for raptors and which stand features are important after the requirements for nest trees have been met (Penteriani, 2002; Lõhmus, 2003a). It is also important to know how much raptors depend on forest site type or tree composition, which (in addition to silvicultural options) determine plant communities and are therefore used to define forest types of conservation concern (e.g. the Habitats Directive of the European Union, 92/43/EEC; Paal, 1997, 2004). Though raptors are often given special protection, it is of general interest whether 'habitat conservation' based on plant communities effectively safeguards animal communities as well.

The home ranges of boreal and temperate tree-nesting raptors usually comprise a mosaic of open country (foraging habitat) and woodland (nesting habitat; also foraging habitat for some species). Several studies highlight the importance of the foraging habitat: (1) its features correlate strongly with raptors' reproductive success (e.g. Lõhmus, 2003b; Lõhmus \& Väli, 2004), even in the species that are extremely demanding with respect to nest trees (Gende et al., 1997; Lõhmus, 2001a); (2) the species that require specific foraging habitats are less numerous (Lõhmus, 2001b). On the other hand, the relationship between population size and nest-site requirements has not been studied yet, and in well-forested areas, nest-site availability is difficult to manipulate in the species that build nests themselves. Hence, it is unclear to what extent the occurrence of suitable trees and stands limits raptor populations in managed forest landscapes.

In this paper, I analyse the nest sites of six most frequent forest raptors that comprise about $85 \%$ of the diurnal raptor communities in Estonia (Lõhmus, 2004b). These include four medium-sized [Honey Buzzard (Pernis apivorus), Goshawk (Accipiter gentilis), Common Buzzard (Buteo buteo), and Lesser Spotted Eagle (Aquila pomarina)] and two small raptors [Sparrowhawk (Accipiter nisus) and Hobby (Falco subbuteo)]. The Hobby uses old nests of corvids, while the other species usually build their nests themselves. The Lesser Spotted Eagle is of European conservation concern (BirdLife International, 2004) and also the Goshawk is strictly protected in Estonia due to its declining numbers; the national populations of the other four species are stable or slowly increasing (Lõhmus, 2004b). 
First, I describe the raptors' nest trees and stands to distinguish their speciesspecific and essential features. Since quantitative data have been published only about the Lesser Spotted Eagle in Estonia (Väli, 2003), the information is presented in detail, and - for direct use in forestry planning - using untransformed univariate approaches. However, I use the multivariate analyses of habitat preferences of the birds (Lõhmus, 2003a) for discussing the significance of different habitat features. Secondly, I explore the links between nest-tree and nest-stand features of three larger species, which were most likely to face the lack of potential nest trees in managed forests. Thirdly, I study the nest-site selectivity of the six species, and check whether this is related to the sizes of their local populations.

\section{MATERIAL AND METHODS}

\section{Study area and the sample of raptor nests}

The main study area was a $900-\mathrm{km}^{2}$ plot with UTM-grid $(10 \times 10 \mathrm{~km})$ borders in east-central Estonia (Fig. 1). Forest land covered 49\%, agricultural lands 36\%, mires $8 \%$, flood-plains $2 \%$, rivers and lakes $2 \%$, and settlements $3 \%$ of the area.

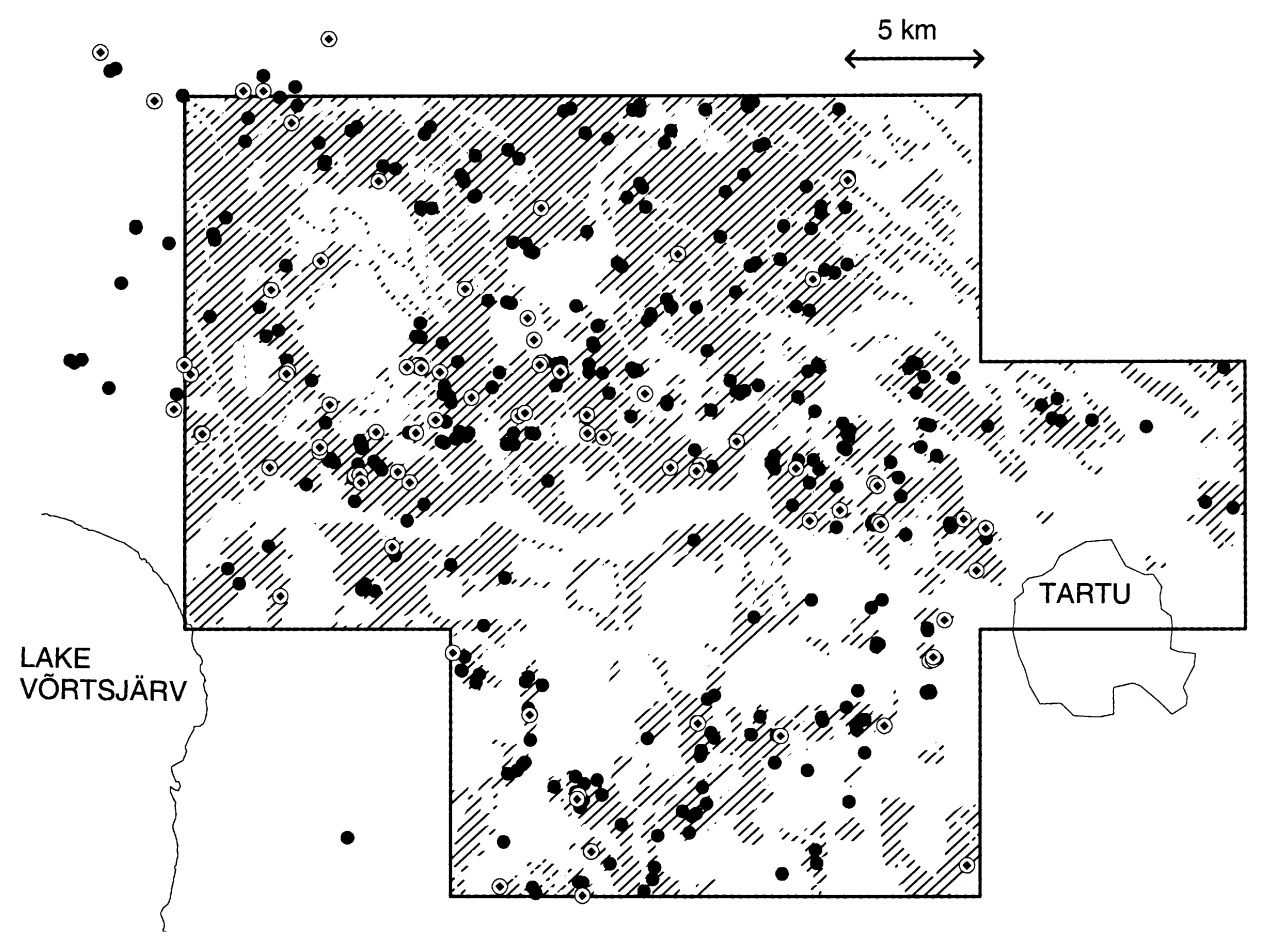

Fig. 1. Location of the main study area, its forests (shaded), and the raptor nests included in the analysis (spots). Filled symbols denote the nests of medium-sized species, hollow symbols are the nests of the Sparrowhawk and the Hobby. 
Due to a long clear-cutting history, most forests had one even-aged tree layer, consisting on average of $46 \%$ birch Betula spp., $17 \%$ Scots pine Pinus sylvestris, $15 \%$ Norway spruce Picea abies, 9\% aspen Populus tremula, $7 \%$ grey alder Alnus incana, $6 \%$ black alder Alnus glutinosa, and 1\% other tree species. The landscape composition was similar to the Estonian average, though the forests contained more birch and fewer coniferous trees. More details about the study area, its forests, bird fauna, and raptor populations can be found elsewhere (Lõhmus, 1997, 2002, 2004c).

Most of the material ( $86 \%$ of nest-site descriptions) has been collected between 1993 and 2001, when nesting territories (an area occupied by a pair over successive years; Steenhof, 1987) and nests of raptors were systematically searched for in the area. Since the main aim of this paper is to study species-specific characteristics of nest sites, I included also the few nests found in the same landscape but outside the main plot (Fig. 1), and those known from 1988-1992 and 2002-2004. This was unlikely to bias the nest-site descriptions but added valuable data about less numerous species. Over the years, about 600 nests of the six species were found, but many of them were harvested or fell down before they could be described, or had been unoccupied for some time and could not be determined to species any more. The sample consisted of 423 nests, for which the occupying species and location were reliably known.

To retain the necessary independence of observations and fully use the data, I used different sub-samples for different purposes: (1) all nest trees for nest-tree analyses; (2) only one nest from each forest stand for stand-scale analyses; (3) only one nest from each nesting territory to analyse the distances from nests to different landscape elements. The about $15 \%$ of nests of medium-sized raptors, which were used by more than one species over the years (Lõhmus, 2003c), have been included in the samples of all relevant species.

\section{Description of the nest sites}

Nest sites may change due to natural disturbances or logging, so their descriptions represent the closest occupancy year to 1997 when most of the randomized surveys of the forests of the study area were carried out (Lõhmus, 2002). In case of equal possibilities, the later year was sampled (e.g. 1998, not 1996; Lõhmus, 2003a). I did not select years randomly, because the number of occupied nests varied non-randomly between years, and the years with more nests would have been overrepresented. For each nest site, I described features of (1) the nest tree and (2) nest stand, as well as (3) the distances from the nest tree to the nearest forest edge, anthropogenic forest edge (field or clear-cut), house, and waterbody.

(1) I recorded the species of the nest tree and measured its height, diameter at breast height (DBH), age (by increment boring), and diameter of nest-supporting branches (the sum of diameters is used for each nest). I also measured the nest height above the ground and recorded the species of the nearest tree. 
(2) In the nest stand, I measured the mean height of the overstorey trees and assessed their species composition at 5\% accuracy within $30 \mathrm{~m}$ around the nest. I estimated canopy closure (\% cover from living overstorey trees; at $10 \%$ accuracy) visually within $5 \mathrm{~m}$ around the nest tree as the mean between the minimum and maximum values. In 117 privately owned nest sites, for which I had sufficient field descriptions (thickness of the peat layer, composition of the tree layer, full species lists of vascular plants around the nest trees), I determined the forest site type according to Lõhmus (1984); the State Forest Database was used for 257 sites in state forests. Stand age (based on increment boring) and site quality class (at a scale $0-6$; larger score indicates worse conditions of tree growth) were obtained from the State Forest Database and represent only the state forests; such data about private forests were not available. The private forests in Jõgeva and Tartu counties are on average 3 years younger and have 0.3 points better site quality than the state forests (Viilup, 2000), so the absolute values presented here are likely to be biased. However, the differences between species as well as the comparison with available stands, which is also based on only state forests, should not be affected.

To analyse the selectivity of different raptor species, I compared the average values of ten nest-site features with those generally available on the landscape. These availability data were obtained from two sources. (1) During 1997-2000 (mostly in 1997), I described 636 random plots in forests, where I assessed stand composition, height, canopy closure, and distances to landscape elements. In addition, I classified the largest (best) tree within $30 \mathrm{~m}$ from each plot centre as suitable or unsuitable for a medium-sized raptor, based on its canopy structure and size. This enabled to analyse separately 229 plots that met the minimum requirements of nest trees for these raptors (for more details, see Lõhmus, 2002; Lõhmus \& Sellis, 2003). (2) Data on the mean site quality were extracted from the State Forest Database. For the medium-sized raptors' sample, I used only the site quality of mature forests.

\section{Data analysis}

Conventional parametric (ANOVA, $t$-tests for independent and paired samples, linear regression) or (if the assumptions of parametric tests were not met) nonparametric statistics (Kruskal-Wallis ANOVA, $\chi^{2}$-test) were used for hypothesis testing. Prior to ANOVA, the distributions of all variables were checked for normality (Kolmogorov-Smirnov test) and homogeneity of variances (Levene's test). Post hoc comparisons were made using Tukey's honestly significant difference (HSD) tests. In addition to the arithmetic mean, which is particularly important for comparisons with other studies, I used quartile range as the main descriptive tool. Compared with other variability statistics, quartile range is robust (does not depend on distribution) and can be directly used to define safe minimum standards for conservation by omitting $25 \%$ of extreme observations. 
Niche breadth was calculated from the frequency distributions of site types and main tree species of stands as the reciprocal Simpson's index: $S=\Sigma\left(p_{i}^{2}\right)^{-1}$, where $p_{i}$ is the relative frequency of category $i$ in the sample. Similarities of the nest sites of the species and random plots were identified with cluster analysis, based on Euclidean distances and the UPGMA method of linkage. The variables were selected carefully to avoid strong intercorrelations (e.g. tree age variables and most distances were omitted) and were standardized before analysis to equalize their relative contributions. The Statistica 6.0 software was used for computations.

\section{RESULTS}

\section{Nest tree}

The raptors built nests on all the main forest trees (Table 1), but conifers, particularly spruce (Fig. 2), were greatly favoured, given their availability on the landscape and in the nest stands. The share of spruce differed significantly among nest trees and the nearest trees in the Sparrowhawk $\left(\chi^{2}{ }_{1}=42.3, P<0.001\right)$, Lesser Spotted Eagle $\left(\chi^{2}{ }_{1}=5.0, P<0.026\right)$, and Honey Buzzard $\left(\chi_{1}^{2}=7.1, P<0.008\right)$, and nearly significantly in the Common Buzzard $\left(\chi^{2}{ }_{1}=2.8, P<0.093\right)$. The tendency was absent in the Hobby, which preferred pines, and it was not significant $\left(\chi^{2}{ }_{1}=0.9, P=0.35\right)$ in the Goshawk, which favoured both species of conifers (Table 1, Fig. 1). Yet, spruce provided the worst, not the best, nest platform for the four larger raptors: the median total diameter of supporting branches was

Table 1. Nest-tree species of common forest-dwelling raptors in east-central Estonia (Papi- Honey Buzzard, Agen - Goshawk, Anis - Sparrowhawk, Bbut - Common Buzzard, Apom - Lesser Spotted Eagle, Fsub - Hobby)

\begin{tabular}{l|r|r|r|r|r|r}
\hline \multirow{2}{*}{ Tree species } & \multicolumn{7}{c}{ Share of nest trees, \% } \\
\cline { 2 - 7 } & Papi & Agen & Anis & Bbut & Apom * & Fsub \\
\hline Picea abies & 64.3 & 36.8 & 91.3 & 42.3 & 68.8 & 18.8 \\
Pinus sylvestris & 2.4 & 36.8 & 7.2 & 20.7 & 0.0 & 81.3 \\
$\quad$ Coniferous trees & $\mathbf{6 6 . 7}$ & $\mathbf{7 3 . 7}$ & $\mathbf{9 8 . 6}$ & $\mathbf{6 3 . 0}$ & $\mathbf{6 8 . 8}$ & $\mathbf{1 0 0 . 0}$ \\
Alnus glutinosa & 19.0 & 0.0 & 0.0 & 2.4 & 0.0 & 0.0 \\
A. incana & 2.4 & 0.0 & 0.0 & 0.0 & 0.0 & 0.0 \\
Betula spp. & 11.9 & 21.1 & 1.4 & 27.4 & 18.8 & 0.0 \\
Quercus robur & 0.0 & 0.0 & 0.0 & 1.0 & 2.1 & 0.0 \\
Padus avium & 0.0 & 0.0 & 0.0 & 0.5 & 0.0 & 0.0 \\
Populus tremula & 0.0 & 5.3 & 0.0 & 5.3 & 8.3 & 0.0 \\
Salix sp. & 0.0 & 0.0 & 0.0 & 0.5 & 0.0 & 0.0 \\
Deciduous trees & $\mathbf{3 3 . 3}$ & $\mathbf{2 6 . 3}$ & $\mathbf{1 . 4}$ & $\mathbf{3 7 . 0}$ & $\mathbf{2 9 . 2}$ & $\mathbf{0 . 0}$ \\
\hline$n$ & 42 & 38 & 69 & 208 & 48 & 16
\end{tabular}

* One nest between an aspen and a spruce. 


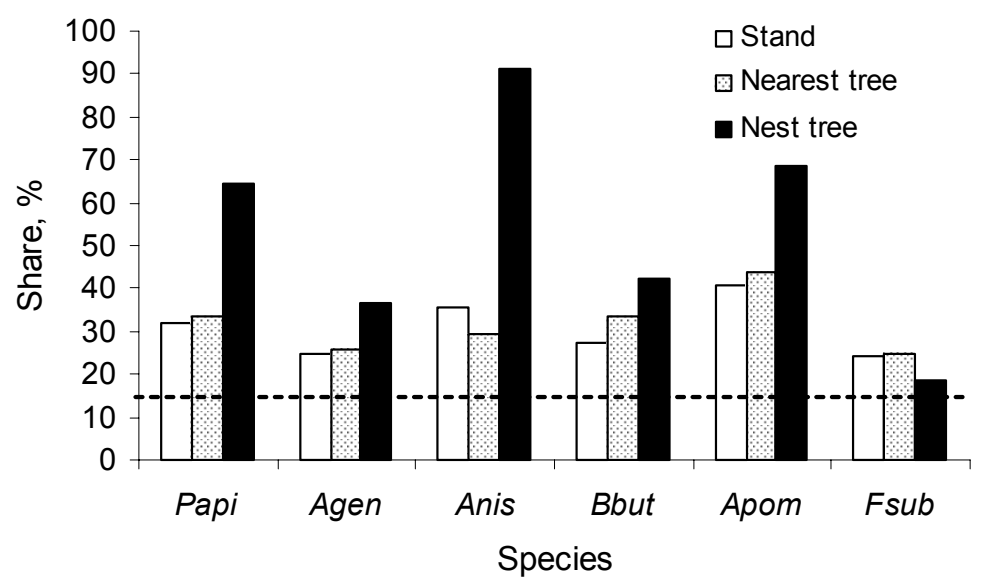

Fig. 2. Share of spruce among nest trees, nearest trees to the nest trees, and in the nest stands of six raptor species. The dashed line indicates the average availability of spruce in the forests of the study area. See Tables 1 and 2 for species abbreviations, sample sizes, and additional data.

smallest in spruce $(13 \mathrm{~cm}$; quartile range 9-19 cm), intermediate in pine $(19 \mathrm{~cm}$; $11-35 \mathrm{~cm}$ ), and largest in deciduous trees $(42 \mathrm{~cm} ; 26-63 \mathrm{~cm})$ (Kruskal-Wallis ANOVA: $\left.H_{2,240}=80.1, P<0.001\right)$.

Compared with the nest trees of other species, the young, small trees and thin branches carrying Sparrowhawk nests were the most distinct (Table 2). Of 16 Hobby nests 12 were in old Raven (Corvus corax) nests on large, old pines; 3 had been built by Hooded Crows (C. corone cornix), and one by the Red Squirrel (Sciurus vulgaris). Across all species, tree size varied less than age: the coefficient of variation ranged between $26 \%$ and $31 \%$ (interspecific mean $=28 \%$ ) for DBH but from $29 \%$ to $39 \%(34 \%)$ for tree age (paired $t$-test: $\left.t_{5}=4.0, P=0.010\right)$. Hence, tree size was generally more important among these intercorrelated variables.

Among the medium-sized raptors, the differences in nest-tree age (ANOVA: $F_{3,229}=2.9, P=0.039$ ) and DBH (ANOVA: $F_{3,285}=2.6, P=0.051$ ) were only due to the Honey Buzzard. This species used thinner trees than the Goshawk (Tukey's test: $P=0.043$ ) and tended to use younger trees than the Goshawk and the Lesser Spotted Eagle ( $P=0.060$ and $P=0.064$, respectively). Therefore, it seemed practical to pool for general nest-tree analyses the two last species and the Common Buzzard, which frequently use each other's nests, but rarely those of the Honey Buzzard (Lõhmus, 2003c). The coniferous nest trees of these three raptors were on average much older (90 years; quartile range 62-112 years) than deciduous trees other than oak (75 and 59-86 years; $t$-test with separate variance estimates: $t_{180}=3.6, P<0.001$ ). The size differences were small and in an opposite direction: the mean DBH was $40 \mathrm{~cm}$ in conifers (quartile range $31-46 \mathrm{~cm}$ ) and $43 \mathrm{~cm}$ in deciduous nest trees $\left(34-50 \mathrm{~cm} ; t_{248}=-2.2, P=0.026\right)$. Two oaks used by Common Buzzards were 71 and 120 years old. 


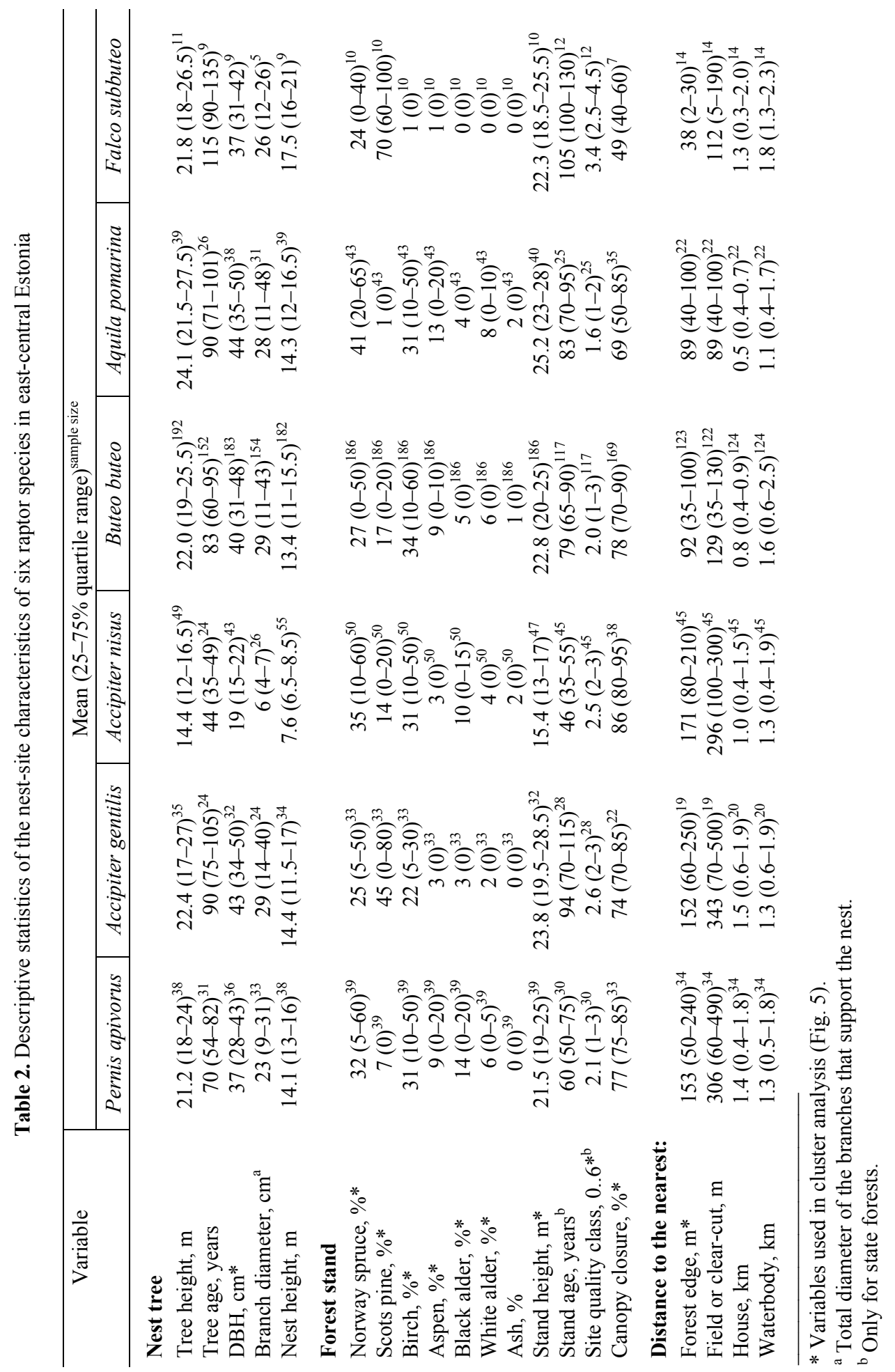




\section{Nest stand}

Raptors nested in all forest site-type groups (STG) of the area, but the use followed the availability only in the Honey Buzzard (Table 3). However, variation among the STG used by the Common Buzzard (niche breadth, $S=4.94$ ), Sparrowhawk $(S=4.39)$, and Goshawk $(S=4.15)$ was also close to that of the available stands $(S=4.77)$. The situation seemed to be similar for the Hobby $(S=5.23)$, whose selectivity could not be tested due to the small sample. Hence, the Lesser Spotted Eagle was the only species with distinct preferences for a few STG $(S=2.51)$ : boreo-nemoral and eutrophic paludifying forests comprised $88 \%$ of its nest stands.

Distribution of the main tree species of the nest stands (Table 3) distinguished three generalist species $(S=3.80$ for the Sparrowhawk, 3.60 for the Honey Buzzard, and 3.23 for the Common Buzzard) and three more stenotopic species: the Hobby ( $S=1.80$; all nest sites in coniferous stands), the Goshawk $(S=2.69 ; 77 \%$ in coniferous stands), and the Lesser Spotted Eagle ( $S=2.68 ; 50 \%$ in spruce stands). Selectivity of the eagle may result from its restricted use of STG, but the Goshawk and Hobby are likely to select stands according to composition (conifers) rather than site type.

The young dense nest stands of the Sparrowhawk and the old sparse pine groves on poor soils used by the Hobby were most distinct structurally (Table 2). Around the Honey Buzzard or Lesser Spotted Eagle nests, pines rarely occurred at all. The site quality differences (ANOVA: $F_{5,251}=7.0, P<0.001$ ) were due to two species. The Hobby used poorer sites than any other raptor (Tukey's test $P=0.068$ when compared with the Sparrowhawk, $P<0.01$ for other comparisons) except the Goshawk $(P=0.20)$, while the Lesser Spotted Eagle used richer sites than the Goshawk and the Sparrowhawk $(P=0.012$ and $P=0.015$, respectively). Among medium-sized species, the Honey Buzzard nested in the youngest (all post hoc comparisons: $P<0.001$; ANOVA: $\left.F_{3,196}=13.0, P<0.001\right)$ and the Goshawk in the oldest stands (contrast with the Common Buzzard, $P=0.008$ ). The Lesser Spotted Eagle used significantly sparser forests than the Common Buzzard and the Honey Buzzard (Tukey's test $P=0.005$ and $P=0.031$, respectively; ANOVA: $\left.F_{3,246}=4.1, P<0.008\right)$.

\section{Links between nest-tree and nest-stand features of medium-sized raptors}

To explore how rotational stand-scale forest management can affect the occurrence of sufficiently large trees for the most demanding species (Goshawk, Lesser Spotted Eagle, Common Buzzard), I used a three-step linear modelling to describe how different tree- and stand-scale variables contribute to the DBH of their nest trees.

(1) The simplest model with tree class (coniferous or deciduous) and age as independent variables indicated that both were significant $(P<0.01)$, but the model only poorly explained the diameter variation $\left(R^{2}=8 \%\right)$. 
Table 3. Frequency distribution of raptor nests according to site-type group and the main tree species of the stand. $\chi^{2}$-tests compare the distribution of site-type groups in raptor nest sites and all state forests (not given for $F$. subbuteo due to the small sample)*

\begin{tabular}{|c|c|c|c|c|c|c|c|c|c|c|c|c|}
\hline \multirow[t]{3}{*}{$\begin{array}{l}\text { Site-type } \\
\text { group }\end{array}$} & \multicolumn{7}{|c|}{$\begin{array}{c}\text { Pernis apivorus } \\
\left(\chi_{4}^{2}=2.9, P=0.57\right)\end{array}$} & \multicolumn{5}{|c|}{$\begin{array}{c}\text { Accipiter gentilis } \\
\left(\chi^{2}{ }_{4}=18.0, P=0.0012\right)\end{array}$} \\
\hline & \multicolumn{6}{|c|}{ Main tree species } & \multirow{2}{*}{$\begin{array}{c}\text { Total } \\
(\%)\end{array}$} & \multicolumn{4}{|c|}{ Main tree species } & \multirow{2}{*}{$\begin{array}{c}\text { Total } \\
(\%)\end{array}$} \\
\hline & Psy & $P a b$ & Bet & Ptr & $\mathrm{Agl}$ & Ain & & Psy & $P a b$ & Bet & Ain & \\
\hline DRY & & & & & & & - & 3 & 1 & & & $3(9)$ \\
\hline MESO & 1 & 1 & 1 & & & & $3(7)$ & 1 & 1 & & & $2(6)$ \\
\hline NEMOR & & 6 & 2 & & & 1 & $9(22)$ & & 3 & 1 & 1 & $4(11)$ \\
\hline EUTR & & 2 & 6 & 1 & 3 & & $12(29)$ & & 1 & 2 & 1 & $4(11)$ \\
\hline OLIGO & & & & & & & - & & & & & - \\
\hline SWAMP & & & 7 & & 4 & & $11(27)$ & 1 & 1 & 1 & & $3(9)$ \\
\hline BOG & & & & & & & - & 4 & & & & $4(11)$ \\
\hline DRAIN & 3 & 3 & & & & & $6(15)$ & 9 & 3 & 3 & & $15(43)$ \\
\hline $\begin{array}{l}\text { Total } \\
(\%)\end{array}$ & $\begin{array}{c}4 \\
(10)\end{array}$ & $\begin{array}{c}12 \\
(29)\end{array}$ & $\begin{array}{c}16 \\
(39)\end{array}$ & $\begin{array}{c}1 \\
\text { (2) }\end{array}$ & $\begin{array}{c}7 \\
(17)\end{array}$ & $\begin{array}{c}1 \\
\text { (2) }\end{array}$ & $\begin{array}{c}41 \\
(100)\end{array}$ & $\begin{array}{c}18 \\
(51)\end{array}$ & $\begin{array}{c}9 \\
(26)\end{array}$ & $\begin{array}{c}7 \\
(20)\end{array}$ & $\begin{array}{c}1 \\
(3)\end{array}$ & $\begin{array}{c}35 \\
(100)\end{array}$ \\
\hline
\end{tabular}

\begin{tabular}{|c|c|c|c|c|c|c|c|c|c|c|c|c|c|}
\hline \multirow[t]{3}{*}{$\begin{array}{l}\text { Site-type } \\
\text { group }\end{array}$} & \multicolumn{7}{|c|}{$\begin{array}{c}\text { Accipiter nisus } \\
\left(\chi_{4}^{2}=11.0, P=0.027\right)\end{array}$} & \multicolumn{6}{|c|}{$\begin{array}{c}\text { Aquila pomarina } \\
\left(\chi^{2}{ }_{4}=21.0, P<0.001\right)\end{array}$} \\
\hline & \multicolumn{6}{|c|}{ Main tree species } & \multirow{2}{*}{$\begin{array}{l}\text { Total } \\
(\%)\end{array}$} & \multicolumn{5}{|c|}{ Main tree species } & \multirow{2}{*}{$\begin{array}{c}\text { Total } \\
(\%)\end{array}$} \\
\hline & Psy & $P a b$ & Bet & Ptr & $A g l$ & Ain & & $P a b$ & Bet & Ptr & $A g l$ & Ain & \\
\hline DRY & 2 & 1 & & & & & $3(5)$ & & & & & & - \\
\hline MESO & & 1 & 1 & & & & $2(4)$ & 1 & & & & & $1(2)$ \\
\hline NEMOR & & 3 & 2 & & & & $5(9)$ & 7 & 7 & 4 & & & $18(43)$ \\
\hline EUTR & & 5 & 4 & 1 & 2 & 1 & $13(24)$ & 10 & 6 & & 1 & 2 & $19(45)$ \\
\hline OLIGO & 1 & & & & & & $1(2)$ & & & & & & - \\
\hline SWAMP & & & 9 & & 7 & & $16(29)$ & & & & & & - \\
\hline BOG & & & & & & - & - & & & & & & - \\
\hline DRAIN & 5 & 3 & 5 & & 2 & & $15(27)$ & 3 & 1 & & & & $4(10)$ \\
\hline $\begin{array}{l}\text { Total } \\
(\%)\end{array}$ & $\begin{array}{c}8 \\
(15)\end{array}$ & $\begin{array}{c}13 \\
(24)\end{array}$ & $\begin{array}{c}21 \\
(38)\end{array}$ & $\begin{array}{c}1 \\
(2)\end{array}$ & $\begin{array}{c}11 \\
(20)\end{array}$ & $\begin{array}{c}1 \\
(2)\end{array}$ & $\begin{array}{c}55 \\
(100)\end{array}$ & $\begin{array}{c}21 \\
(50)\end{array}$ & $\begin{array}{c}14 \\
(33)\end{array}$ & $\begin{array}{c}4 \\
(10)\end{array}$ & $\begin{array}{c}1 \\
(2)\end{array}$ & $\begin{array}{c}2 \\
(5)\end{array}$ & $\begin{array}{c}42 \\
(100)\end{array}$ \\
\hline
\end{tabular}

\begin{tabular}{|c|c|c|c|c|c|c|c|c|c|c|c|}
\hline \multirow{3}{*}{$\begin{array}{l}\text { Site-type } \\
\text { group }\end{array}$} & \multicolumn{8}{|c|}{ Buteo buteo $\left(\chi_{4}^{2}=77.4, P<0.001\right)$} & \multicolumn{3}{|c|}{ Falco subbuteo } \\
\hline & \multicolumn{7}{|c|}{ Main tree species } & \multirow[t]{2}{*}{$\begin{array}{l}\text { Total } \\
(\%)\end{array}$} & \multicolumn{2}{|c|}{$\begin{array}{c}\text { Main tree } \\
\text { species }\end{array}$} & \multirow[t]{2}{*}{$\begin{array}{c}\text { Total } \\
(\%)\end{array}$} \\
\hline & Psy & $P a b$ & Bet & Ptr & $A g l$ & Ain & Qro & & Psy & $P a b$ & \\
\hline DRY & 10 & 2 & 2 & & & & & $14(8)$ & 4 & & $4(27)$ \\
\hline MESO & 9 & 4 & 5 & 2 & & & 1 & $21(11)$ & 1 & & $1(7)$ \\
\hline NEMOR & 1 & 16 & 26 & 12 & & 4 & & $59(32)$ & & 2 & $2(13)$ \\
\hline EUTR & & 10 & 22 & & 2 & 3 & & $37(20)$ & & & - \\
\hline OLIGO & 1 & & & & & & & $1(1)$ & 3 & & $3(20)$ \\
\hline SWAMP & & & 15 & & 2 & & & $17(9)$ & & & - \\
\hline BOG & 2 & & & & & & & $2(1)$ & 2 & & $2(13)$ \\
\hline DRAIN & 15 & 7 & 13 & & & & & $35(19)$ & & 3 & $3(20)$ \\
\hline $\begin{array}{l}\text { Total } \\
(\%)\end{array}$ & $\begin{array}{c}38 \\
(20)\end{array}$ & $\begin{array}{c}39 \\
(21)\end{array}$ & $\begin{array}{c}83 \\
(45)\end{array}$ & $\begin{array}{c}14 \\
(8)\end{array}$ & $\begin{array}{c}4 \\
\text { (2) }\end{array}$ & $\begin{array}{c}7 \\
\text { (4) }\end{array}$ & $\begin{array}{c}1 \\
(1)\end{array}$ & $\begin{array}{c}186 \\
(100)\end{array}$ & $\begin{array}{c}10 \\
(67)\end{array}$ & $\begin{array}{c}5 \\
(33)\end{array}$ & $\begin{array}{c}15 \\
(100)\end{array}$ \\
\hline
\end{tabular}

* Abbreviations: DRY - dry boreal, MESO - meso-eutrophic, NEMOR - boreo-nemoral, EUTR eutrophic paludifying, OLIGO - oligotrophic paludifying, SWAMP - swamp, BOG - bog, DRAIN drained peatland forests; $P s y$ - Scots pine, $P a b$ - Norway spruce, Bet - birch, Ptr - aspen, $A g l$ - black alder, Ain - white alder, Qro - oak. For testing, I pooled DRY with MESO, EUTR with OLIGO, and SWAMP with BOG (see Lõhmus, 1984). 
(2) Site-quality index improved the model considerably: the tree variables retained their importance, site quality classified as highly significant $(P<0.001)$, and the whole model explained $27 \%$ of the variation. A separate analysis confirmed that nest trees were also older on poor than on more fertile soils, where the trees could reach sufficient size more quickly (Fig. 3). However, the strong negative relationships between DBH and site quality both in coniferous $\left(r_{89}=-0.27, P=0.010\right)$ and deciduous trees $\left(r_{52}=-0.41, P=0.002\right)$ indicated that the generally older trees in poorer sites were still smaller than those in more fertile sites.

(3) Stand age was related positively to DBH and added further explanatory ability to the model $\left(R^{2}=35 \%\right)$; all four variables retained significance at $\alpha=0.05$. Though the age of the nest tree $(y)$ should depend on the stand age $(x)$ in evenaged forestry, this regression $(y=53.0+0.43 x$; slope $\mathrm{SE}=0.12, P<0.001)$ explained only $10 \%$ of the variation and its slope differed significantly from $1: 1$. One reason for the disproportion was the relatively old age of nest trees in young forests and vice versa, so that stands less than 80 years old were generally used only if they contained older trees (Fig. 4). Hence, the independent effect of stand age on tree size was rather correlational than causal, i.e. large trees are concentrated into old forests but such trees can be used also in younger forests if provided.

Table 4 lists the DBH and age of the nest trees and the age of the forest stands that could be used as practical minima for the medium-sized raptors. Note that the

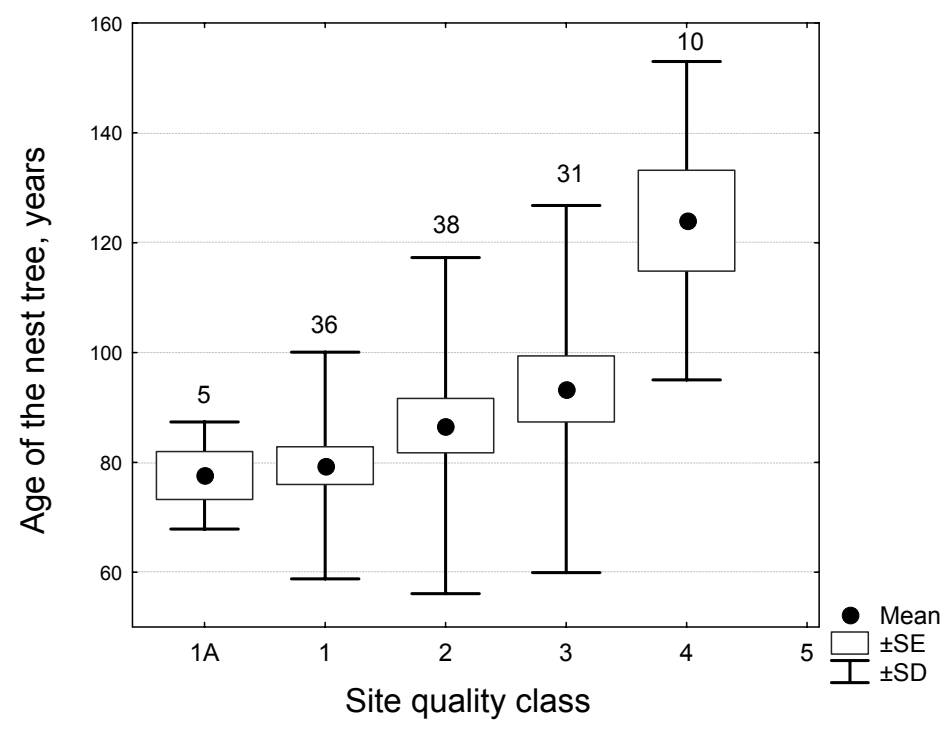

Fig. 3. Age of the nest tree in relation to site quality class in the Goshawk, Common Buzzard, and Lesser Spotted Eagle ( $n=121$ nests). In class 5, only one 167-year-old nest tree was measured. Numbers indicate sample sizes. 


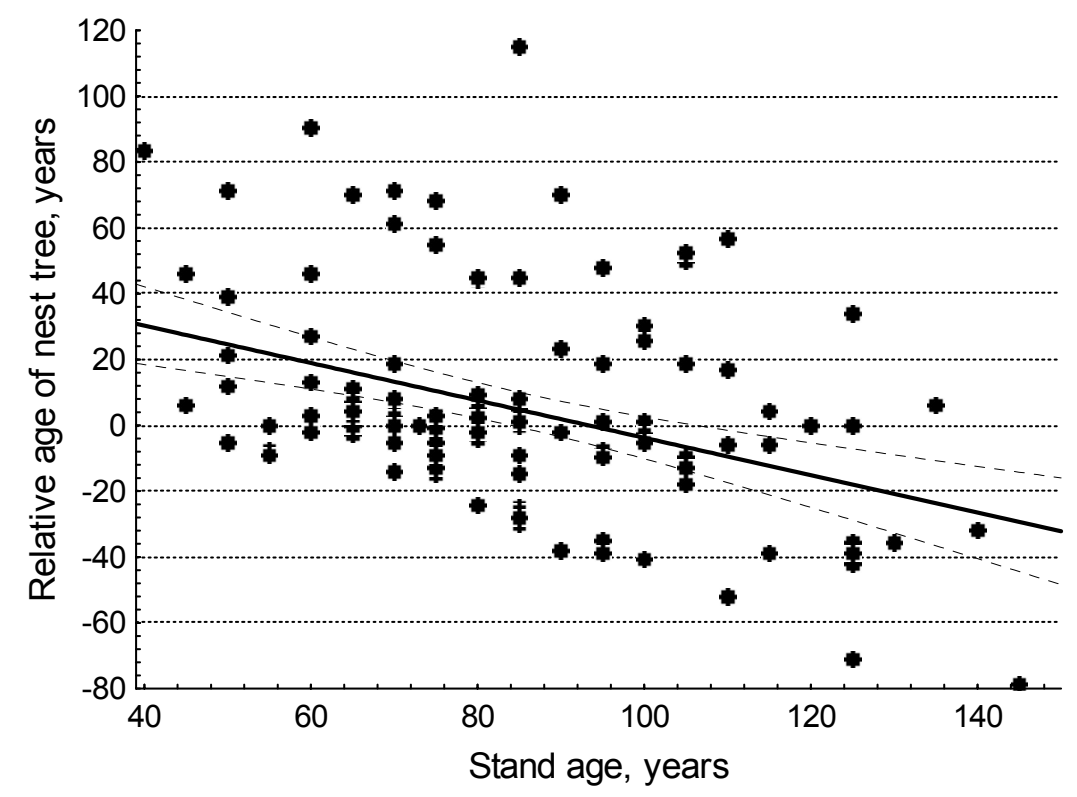

Fig. 4. Relative age of the nest tree (compared with stand age) in relation to stand age in the Goshawk, Common Buzzard, and Lesser Spotted Eagle ( $n=121$ nests). The regression line and its $95 \%$ confidence intervals are shown (slope: $-0.57 \pm 0.12$ S.E., $P<0.001$; intercept $53.0 \pm 10.5$ S.E., $P<0.001)$.

stand ages should be used to evaluate the suitability of current forests rather than as future targets if green-tree retention and uneven-aged practices become more popular. It can be also seen that the relationship between tree age and site quality is pronounced in coniferous, and not deciduous, trees.

The species were clearly separated by the distances from the nest to the nearest forest edge: $75 \%$ of the Hobby nests were situated up to $30 \mathrm{~m}$ from the edge; the Lesser Spotted Eagle and Common Buzzard nested at intermediate

Table 4. Recommended minimum DBH and age of nest trees, and the age of nest stands of mediumsized raptors, depending on site quality and tree type in Estonia. The numbers are $25 \%$-quartiles (ages at 5-year accuracy) of the pooled samples of three species (Goshawk, Lesser Spotted Eagle, Common Buzzard)

\begin{tabular}{l|c|c}
\hline \multirow{2}{*}{ Site quality class } & \multicolumn{2}{|c}{ DBH, cm (tree age/stand age, yr) } \\
\cline { 2 - 3 } & Coniferous trees & Deciduous trees \\
\hline \multirow{2}{*}{$1 \mathrm{~A}, 1$} & $32(65 / 65)$ & $45(65 / 70)$ \\
2 & $31(65 / 65)$ & $37(70 / 65)$ \\
3 & $30(85 / 75)$ & $33(65 / 70)$ \\
4 & $27(125 / 70)$ & $28(70 / 65)$
\end{tabular}


distances ( $50 \%$ of the nests $35-100 \mathrm{~m}$ ), and the Honey Buzzard, Goshawk, and Sparrowhawk were forest-dwellers (Table 2). However, these species had no pronounced preference for forest interior (the mean distance to edges from random plots: $162 \pm 12 \mathrm{~m}$ ). The Lesser Spotted Eagle was the species that nested closest to anthropogenic edges and houses, though the differences from the Common Buzzard were not significant.

\section{Nest-site selectivity}

Ten variables were selected for the analysis of nest site selectivity of the six species (Table 2). Cluster analysis indicated that, compared with randomly selected forest plots, the Honey Buzzard was the least, and the Sparrowhawk and the Hobby were the most demanding species in this forest landscape (Fig. 5). The Goshawk seemed to be the most tolerant as far as nest-tree requirements were fulfilled (rather similar to the random plots having suitable trees), while the Common Buzzard and the Lesser Spotted Eagle were grouped into a separate cluster and formed the most similar species pair. The general selectivity for nest site (Euclidean distance from the mean values of random plots) was not related to population sizes of the species (according to Lõhmus, 1997) or to the selectivity for foraging areas (according to Lõhmus, 2001b; Fig. 6).

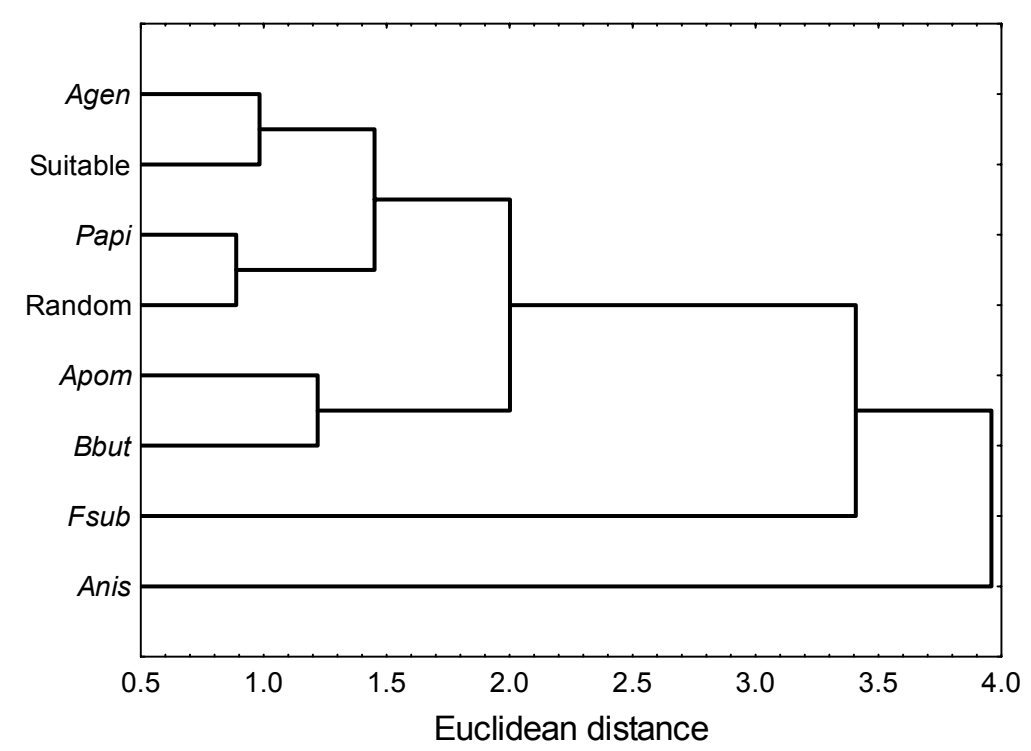

Fig. 5. Similarity of raptor nest sites and random forest plots ('random' $=$ all plots, 'suitable' $=$ plots with at least one tree suitable for nest-building within $30 \mathrm{~m}$ ). Data comprised the mean values of ten variables (Table 2) and UPGMA method was used for clustering. See Table 1 for the abbreviations of species names. 

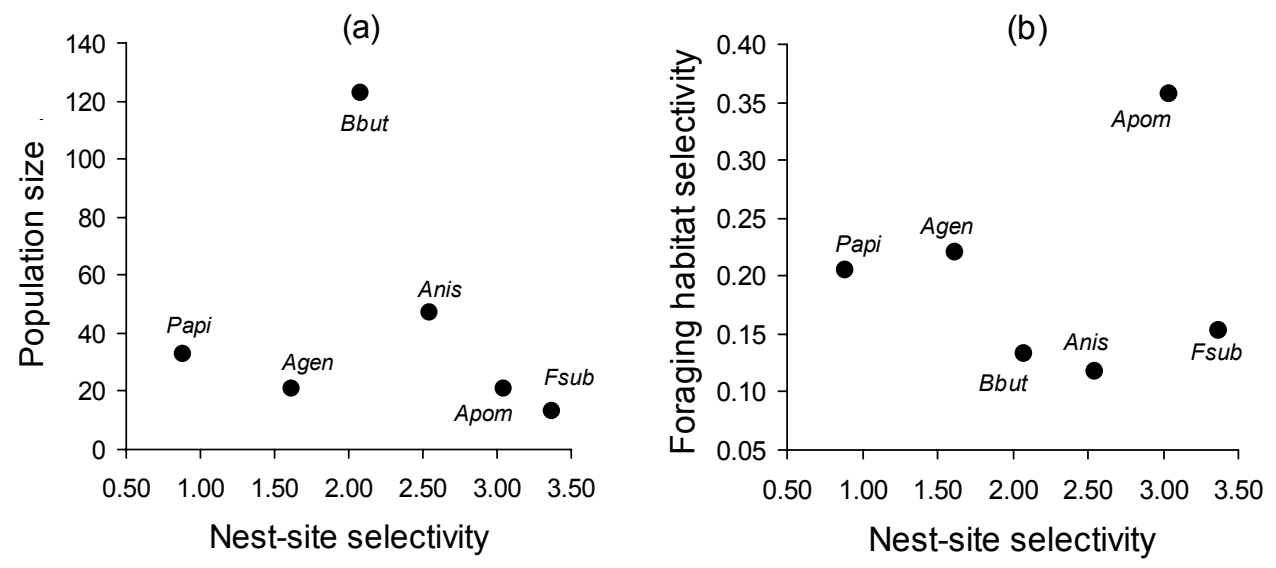

Fig. 6. Nest-site selectivity of six raptor species in east-central Estonia in relation to their population size (a) and selectivity towards foraging habitat (b). Nest-site selectivities were measured as Euclidean distances between the mean values of stand characteristics in raptor nest sites and random forest plots. See Table 1 for the abbreviations of species names.

\section{DISCUSSION}

\section{Covariation and trade-offs in raptors' habitat selection}

Environmental covariation confuses wildlife habitat studies, because critical habitat features are difficult to distinguish among simultaneous 'effects' of correlated (and possibly unknown) variables. For example, the similar speciesspecific differences in nest-tree and nest-stand features of forest raptors (Table 2) raised the question about the independent contribution of stand characteristics. Therefore, an increasing number of studies pool many variables into models or combined factors (reviewed by Lõhmus, 2004a). While such models are useful for many purposes (overview of habitat requirements, predicting occurrence in new areas, ranking sites for conservation), they are often too complicated to provide managers with clear targets for action. Hence, special studies should complement multivariate analyses to extract practical tools for species management.

I analysed, and discuss below in the light of other studies and multivariate models (Lõhmus, 2003a), (1) the trade-off situations in the raptors' preference for spruce, and in the use of sites on poorer soils by medium-sized species; (2) the covariation between the nest-tree age, size, and the age of the nest stand, and between the nest-tree species and stand composition. The landscape-scale tradeoff between the proximity of foraging habitat (meadow, field, clear-cut) and human disturbance has been explored with a larger data set in the Lesser Spotted Eagle (Väli et al., 2004). In fact, this species of conservation concern tended to nest closer to houses than any other common raptor in east-central Estonia (Table 2).

Several studies have shown the preference of diurnal raptors for coniferous nest trees in temperate and boreal areas, and most have explained this with better 
protective cover (e.g. Joensen, 1968; Bosakowski et al., 1992; Yahner \& Grimm, 1993; England et al., 1995; Newton, 1996). Indeed, after commercial thinning, Sparrowhawks re-occupied only spruce stands in Norway (Selås, 1996) and two studies relate better reproductive success to nesting on conifers (Spitzer, 1980; Warkentin \& James, 1988). However, my study is the first to confirm the hypothesis of Solonen (1982) that by selecting spruce, larger raptors may trade off the stability of the nest platform for the cover. Therefore, it could be less meaningful for them to nest on conifers in areas with few natural predators, no human persecution, and favourable climate.

Multivariate models reveal a preference for coniferous stands (independent of tree size and location on the landscape) by the four medium-sized raptors, but not the Sparrowhawk (Lõhmus, 2003a; Hobby not analysed). I could not test whether such a preference reflected simply the nest-tree preference. However, circumstantial evidence suggested an independent effect at least in the Goshawk, which had the least preference for nest-tree species, yet it used a narrow range of stand compositions. Moreover, since the occurrence of individual trees cannot be followed in forestry planning, stand composition (e.g. the ranges shown in Table 2) is probably an important target variable for management anyway.

Nest-tree age has been measured in relatively few raptor studies, and its effect additional to tree size, as well as relationships with site quality and stand age, has not been analysed. I found a complicated pattern of interactions, with all these factors contributing. Size of the nest tree was indeed more decisive than age as judged from (1) its smaller variance (discussion on this criterion: McCallum \& Gehlbach, 1988; Clark \& Shutler, 1999), and (2) small differences in DBH, but contrasting age, of conifers and deciduous trees. Bergmanis (2004) found also a 25 -year difference between the mean ages of deciduous and coniferous nest trees of the Lesser Spotted Eagle, and suggested that tree diameter, not age, determines its suitability. However, medium-sized raptors used smaller and older trees on poor soils, i.e. the age-related increase in size did not balance DBH across site quality classes. This indicates an independent effect of tree age: slowly grown trees may have relatively stronger branches than fast-grown trees of similar size. Moreover, while such a combined effect with site quality was clear in coniferous nest trees, deciduous trees had similar age limit but decreasing DBH from rich to poor sites (Table 4). Given that $71 \%$ of the 92 nests of the three larger raptors on deciduous trees were situated in tree forks, the age at which such forks develop may determine the nesting possibilities there.

To my knowledge, the additional effect of stand age on nest-tree age has not been analysed in diurnal raptors before. It was, however, not found in the Estonian Black Stork (Ciconia nigra) population, which is partly limited by the lack of nest trees (Lõhmus \& Sellis, 2003; Lõhmus et al., 2005). Also in my study, nest-tree age was by far more important than stand age for medium-sized raptors (Fig. 4), though there was an additional effect on tree size. Natural stand structure improves the probability of raptor nesting independently of tree size (Lõhmus, 2003a; Lõhmus \& Väli, 2005), but it does not explain the current effect - the raptors did not accept relatively smaller trees in old stands. On the contrary, after correcting 
for tree species, age, and site quality, the nest trees were still larger there. The reason is obscure but, as a consequence, the relatively large trees in old stands may support nests better, i.e. old forests may guarantee the occupancy of nest sites for longer periods.

\section{Management implications}

This study enables practical conclusions about (1) green-tree retention during clear-cutting and the protection of certain site types as techniques for protecting and restoring raptor habitats; (2) variables for predictive habitat models; and (3) nest sites as a limiting factor for the forest raptors in the studied landscape.

It is well known that large eagles cannot find suitable trees for their huge nests in even-aged commercial forests, unless such trees have been purposefully retained (e.g. Tjernberg, 1983). I found that also the Goshawk, Lesser Spotted Eagle, and Common Buzzard generally inhabited younger than 80 -year-old stands only in the presence of older trees. Given that most deciduous stands are suitable for clear-cutting already at 60 years and coniferous stands at 80 years of age in Estonia, green-tree retention could greatly add nest sites for these medium-sized raptors in managed forests. There are, however, limitations. First, large eagles may be better adapted to nest on single trees in open sites than smaller species, which are prone to predation and bad weather. Such raptors may not accept retention trees before the young stand has started to provide sufficient cover. This time lag (c. 30 years) should be taken into account when planning the continuity of nest sites and the number of trees to be retained at harvests (at least two-thirds of the trees are likely to be lost by that time; Rosenvald \& Lõhmus, 2005). Secondly, spruce (the preferred nest tree) is very wind prone and cannot be retained on clear-cuts. Hence, partial harvesting in spruce-containing stands might provide considerably better habitat for medium-sized raptors as far as some large spruces are always retained. Such a management of boreo-nemoral or eutrophic paludifying forests may be particularly important for a healthy population of the Lesser Spotted Eagle in Estonia and adjacent countries (cf. Bergmanis, 2004). For other raptors, which inhabit a broad array of site types, site-type based management or reserve selection are not as useful.

Predictive habitat modelling is an important management tool for assessing the suitability of landscapes for target species, planning for the change, and for finding sites occupied by species of conservation concern (e.g. Angelstam et al., 2004). My study distinguished five main factors to be taken into account for forest raptors: (1) stand age and (2) stand composition as substitutes for tree age and species in stand-scale management; (3) site quality; (4) canopy closure (or stand density as measured in forest inventories); and (5) the distance to forest edge. The proposed criteria (Table 5), based on Table 2 and Drobelis (1990), could be used over most of the mainland Estonia (except perhaps the western and north-western regions where pine forests dominate) and possibly in the surrounding Latvian and Russian regions. However, it would be important to confirm these criteria in the future. 
Table 5. Practical criteria of suitable and high-quality nest sites of forest raptors in Estonia

\begin{tabular}{|c|c|c|c|c|c|}
\hline \multirow[t]{2}{*}{ Species } & \multicolumn{5}{|c|}{ Criteria of suitable (high-quality) sites } \\
\hline & $\begin{array}{l}\text { Stand age, } \\
\text { min or } \\
\text { range }\end{array}$ & Stand composition* & \begin{tabular}{|c|} 
Site \\
quality
\end{tabular} & $\begin{array}{c}\text { Canopy } \\
\text { closure, } \\
\%\end{array}$ & $\begin{array}{c}\text { Field or } \\
\text { clear-cut, } \\
\mathrm{m}\end{array}$ \\
\hline Pernis apivorus & $50(60)$ & $<10 \%$ Psy; Pab or $\mathrm{Agl}$ present & $<4$ & $\geq 70$ & $>50$ \\
\hline Accipiter gentilis & $70(90)^{* *}$ & $\geq 50 \% P s y+P a b$ & $<5$ & $\geq 70$ & $>70$ \\
\hline A. nisus & $35-55$ & $\geq 5 \%(\geq 20 \%) P a b$ & $<5$ & $\geq 80$ & $>30(>100)$ \\
\hline Buteo buteo & $60(80)^{* *}$ & & $<5$ & $\geq 50(70-90)$ & $40-200$ \\
\hline Aquila pomarina & $70(80)$ & $<5 \%$ Psy; $\geq 20 \% P a b$ & $<3$ & $40-90$ & 40-200 \\
\hline Falco subbuteo & 100 & $\geq 60 \%$ Psy or $\geq 90 \%$ Psy $+P a b$ & $>2$ & $<90(40-60)$ & Any edge $<100$ \\
\hline
\end{tabular}

* See the abbreviations in Table 3.

** Add 10 years for sites of quality class 3 , and 30 years for quality class 4 (cf. Table 4 ).

Correlative evidence on population limitation can fail for several reasons (Newton, 1998), but I argue that my results can be interpreted in these terms. Given that either nest sites or food (whichever is in shorter supply) determine the density of breeding raptor populations (Newton, 1979), it is noteworthy that in this area, selectivity for foraging areas correlated with raptor densities (Lõhmus, 2001b), whereas the nest-site selectivity did not (Fig. 6). Moreover, the features of foraging habitats, and not nest sites, were related to the productivity of the Common Buzzard (Lõhmus, 2003b; unpubl. data). It is also difficult to explain the recent decline of the Goshawk with the lack of nest sites, given its relatively low selectivity for characteristics other than nest tree (Fig. 6; see also Widén, 1997). Hence, foraging habitat (i.e., food) is probably the main limiting factor for the forest raptor populations studied. This does not mean, however, that their nest sites need no attention, given the current trends of forest management in Estonia. In fact, my study highlighted that (1) the recent intensive conifer-biased harvesting (Kuuba, 2001) has probably reduced the raptors' nest-site supply even beyond the general loss of old-growth (Lõhmus, 2002); and (2) the protected forests, which are predominately on poor soils (Lõhmus et al., 2004), may often not meet the raptors' requirements. A major reason for this is that only very old conifers are suitable in such forests (quality classes 3 and 4; Table 4), i.e. even mature stands may lack potential nest trees there.

\section{ACKNOWLEDGEMENTS}

I am grateful to Piret Lõhmus, Reimo Rander, and Ülo Väli for field assistance, and to Raul Rosenvald (Estonian Agricultural University) for help with the State Forest Database. Ülo Väli also provided constructive comments on the manuscript. The study was partly financed by the Estonian Science Foundation (grants Nos 5257 and 6457). 


\section{REFERENCES}

Angelstam, P., Roberge, J.-M., Lõhmus, A., Bergmanis, M., Brazaitis, G., Dönz-Breuss, M., Edenius, L., Kosinski, Z., Kurlavičius, P., Larmanis, V., Lukins, M., Mikusinski, G., Račinskis, E., Stradzs, M. \& Tryjanowski, P. 2004. Habitat modelling as a tool for landscape-scale conservation - a review of parameters for focal forest birds. Ecol. Bull., 51, $427-453$.

Bergmanis, U. 2004. Analysis of breeding habitats of the Lesser Spotted Eagle Aquila pomarina in Latvia. In Raptors Worldwide (Chancellor, R. D. \& Meyburg, B.-U., eds), pp. 537-550. WWGBP/MME, Budapest.

Bielánski, W. 2004. Impact of common silvicultural treatments on nest tree accessibility for Common Buzzard Buteo buteo and Goshawk Accipiter gentilis. Ornis Fenn., 81, 180-185.

BirdLife International. 2004. Birds in Europe: Population Estimates, Trends and Conservation Status. BirdLife International, Cambridge.

Bosakowski, T., Smith, D. G. \& Speiser, R. 1992. Niche overlap of two sympatric-nesting hawks Accipiter spp. in the New Jersey-New York Highlands. Ecography, 15, 358-372.

Clark, R. G. \& Shutler, D. 1999. Avian habitat selection: pattern from process in nest-site use by ducks? Ecology, 80, 272-287.

Del Hoyo, J., Elliott, A. \& Sargatal, J. (eds) 1994. Handbook of the Birds of the World. Vol. 2. Lynx Editions, Barcelona.

Drobelis, E. 1990. On biology of some birds of prey in Lithuania. Acta Ornithol. Lituanica, 2, 90103.

England, A. S., Estep, J. A. \& Holt, W. R. 1995. Nest-site selection and reproductive performance of urban-nesting Swainson's hawks in the central valley of California. J. Raptor Res., 29, 179-186.

Fuller, M. R. 1996. Forest raptor population trends in North America. In Conservation of Faunal Diversity in Forested Landscapes (DeGraaf, R. M. \& Miller, R. I., eds), pp. 167-208. Chapman \& Hall, London.

Gende, S. M., Willson, M. F. \& Jacobsen, M. 1997. Reproductive success of bald eagles (Haliaeetus leucocephalus) and its association with habitat or landscape features and weather in southeast Alaska. Can. J. Zool., 75, 1595-1604.

Joensen, A. H. 1968. An investigation on the breeding population of the Buzzard (Buteo buteo) on the island Als in 1962 and 1963. Dansk Orn. Foren. Tidsskr., 62, 17-31.

Jullien, M. \& Thiollay, J. M. 1996. Effects of rain forest disturbance and fragmentation: Comparative changes of the raptor community along natural and human-made gradients in French Guiana. J. Biogeogr., 23, 7-25.

Kontkanen, H., Nevalainen, T. \& Lõhmus, A. 2004. Röövlinnud ja metsamajandus. Eesti Entsüklopeediakirjastus, Tallinn.

Kuuba, R. 2001. The dynamics and the character of harvest rates in Estonia during the last decade of the 20th century. Metsanduslikud uurimused, 35, 59-73.

Lõhmus, A. 1997. Population changes of raptors and owls in northwestern Tartumaa. Hirundo, 10, 4-16.

Lõhmus, A. 2001a. Habitat selection in a recovering Osprey Pandion haliaetus population. Ibis, 143, 651-657.

Lõhmus, A. 2001b. Selection of foraging habitats by birds of prey in north-western Tartumaa. Hirundo, 14, 27-42.

Lõhmus, A. 2002. The lack of old-growth forest - a threat to Estonian biodiversity. Proc. Estonian Acad. Sci. Biol. Ecol., 51, 138-144.

Lõhmus, A. 2003a. Habitat preferences and habitat quality for birds of prey: from principles to applications. Diss. Biol. Univ. Tartu., 78. 
Lõhmus, A. 2003b. Are certain habitats better every year? A review and a case study on birds of prey. Ecography, 26, 545-552.

Lõhmus, A. 2003c. Is it possible to determine the occupying species and nest age from dimensions of raptor nests? Hirundo, 16, 3-13.

Lõhmus, A. 2004a. Raptor habitat studies - the state of the art. In Raptors Worldwide (Chancellor, R. D. \& Meyburg, B.-U., eds), pp. 279-296. WWGBP/MME, Budapest.

Lõhmus, A. 2004b. Monitoring of raptors and owls in Estonia, 1999-2003: decline of the Goshawk and the clockwork of vole-cycles. Hirundo, 17, 3-18.

Lõhmus, A. 2004c. Breeding bird communities in two Estonian forest landscapes: are managed areas lost for biodiversity conservation? Proc. Estonian Acad. Sci. Biol. Ecol., 53, 52-67.

Lõhmus, A. \& Sellis, U. 2003. Nest trees - a limiting factor for the the Black Stork (Ciconia nigra) population in Estonia. Aves, 40, 84-91.

Lõhmus, A. \& Väli, Ü. 2004. The effects of habitat quality and female size on the productivity of the Lesser Spotted Eagle Aquila pomarina in the light of the alternative prey hypothesis. J. Avian Biol., 35, 455-464.

Lõhmus, A. \& Väli, Ü. 2005. Habitat use by the vulnerable greater spotted eagle Aquila clanga, interbreeding with the lesser spotted eagle A. pomarina in Estonia. Oryx, 39, 170-177.

Lõhmus, A., Kohv, K., Palo, A. \& Viilma, K. 2004. Loss of old-growth, and the minimum need for strictly protected forests in Estonia. Ecol. Bull., 51, 401-411.

Lõhmus, A., Sellis, U. \& Rosenvald, R. 2005. Have recent changes in forest structure reduced the Estonian black stork Ciconia nigra population? Biodivers. Cons., 14, 1421-1432.

Lõhmus, E. 1984. Eesti metsakasvukohatüübid. ENSV Agrotööstuskoondise Info- ja Juurutusvalitsus, Tallinn.

McCallum, D. A. \& Gehlbach, F. R. 1988. Nest-site preferences of Flammulated owls in western New Mexico. Condor, 90, 653-661.

Newton, I. 1979. Population Ecology of Raptors. Poyser, Berkhamsted.

Newton, I. 1996. Sparrowhawks in conifer plantations. In Raptors in Human Landscapes (Bird, D., Varland, D. \& Negro, J. J., eds), pp. 191-199. Academic Press, London.

Newton, I. 1998. Population Limitation in Birds. Academic Press, London.

Niemi, G. J. \& Hanowski, J. M. 1997. Concluding remarks on raptor responses to forest management: a holarctic perspective. J. Raptor Res., 31, 191-196.

Paal, J. 1997. Eesti taimkatte kasvukohatüüpide klassifikatsioon. Keskkonnaministeeriumi Info- ja Tehnokeskus, Tallinn.

Paal, J. 2004. Euroopas vä̈̈rtustatud elupaigad Eestis. Eesti Keskkonnaministeerium, Tallinn.

Penteriani, V. 2002. Goshawk nesting habitat in Europe and North America: a review. Ornis Fenn., 79, 149-163.

Petty, S. J. 1998. Ecology and Conservation of Raptors in Forests. Forestry Commission Bulletin, 118 , London, UK.

Reynolds, R. T., Graham, R. T., Reiser, M. H., Basset, R. L., Kennedy, P. L., Boyce, D. A. Jr., Goodwin, G., Smith, R. \& Fisher, E. L. 1992. Management Recommendations for the Northern Goshawk in the Southwestern United States. General Technical Report RM-217. USDA Forest Service, Fort Collins, Colorado.

Rosenvald, R. \& Lõhmus, A. 2005. Säilikpuud raiesmikel: kelle jaoks ja kui palju? Eesti Mets, 1, 33-38.

Saurola, P. 1997. The osprey (Pandion haliaetus) and modern forestry: a review of population trends and their causes in Europe. J. Raptor Res., 31, 129-137.

Selås, V. 1996. Selection and reuse of nest stands by Sparrowhawks Accipiter nisus in relation to natural and manipulated variation in tree density. J. Avian Biol., 27, 56-62.

Solonen, T. 1982. Nest-sites of the Common Buzzard Buteo buteo in Finland. Ornis Fenn., 59, 191-192.

Spitzer, G. 1980. Die Bedeutung der Situation des Horstbaumes für den Aufzuchtserfolg beim Mäusebussard. J. Orn., 121, 323-324. 
Steenhof, K. 1987. Assessing raptor reproductive success and productivity. In Raptor Management Techniques Manual (Pendleton, B. A. G., Millsap, B. A., Cline, K. W. \& Bird, D. M., eds), pp. 157-170. Natl. Wildl. Fed., Washington, D.C.

Tjernberg, M. 1983. Habitat and nest site features of golden eagles Aquila chrysaetos (L.) in Sweden. Swed. Wildl. Res., 12, 131-163.

Väli, Ü. 2003. The lesser spotted eagle and its conservation in Estonia. Hirundo Suppl., 6.

Väli, Ü., Treinys, R. \& Lõhmus, A. 2004. Geographical variation in macrohabitat use and preferences of the Lesser Spotted Eagle Aquila pomarina. Ibis, 146, 661-671.

Viilup, Ü. 2000. Forest resources. In Aastaraamat Mets 2000, pp. 1-38. Metsakaitse- ja Metsauuenduskeskus, Tartu.

Warkentin, I. G. \& James, P. C. 1988. Nest-site selection by urban merlins. Condor, 90, 734-738.

Widén, P. 1997. How, and why, is the goshawk (Accipiter gentilis) affected by modern forest management in Fennoscandia? J. Raptor Res., 31, 107-113.

Yahner, R. H. \& Grimm, J. W. 1993. Nest-tree use by hawks in Pennsylvania. J. Pennsylvania Acad. Sci., 67, 40-41.

\title{
Kulliliste pesapuud ja pesitsuspuistud Kesk-Eesti idaosas: metsanduslikud ja looduskaitseaspektid
}

\begin{abstract}
Asko Lõhmus
Ohustatud liikide elupaikade kaitseks täpsete soovituste andmist takistavad sageli eri elupaigatunnuste seotus ja elupaikade piirkondlik varieeruvus. KeskEesti idaosas uuriti kuue kõige sagedama kulliliseliigi 423 pesa eesmärgiga: 1) määratleda pesapaikade olulisimad ja tunnuslikud omadused, 2) kirjeldada seoseid pesapuu ja pesitsuspuistu tunnuste vahel, 3) hinnata, kas potentsiaalsete pesapuude ja -puistute hulk piirab metsakulliliste arvukust. Ainult väike-konnakotkal (Aquila pomarina) leiti kitsapiiriline eelistus metsakasvukohatüübi suhtes; kanakull (Accipiter gentilis) ja lõopistrik (Falco subbuteo) valisid aga puistuid pigem puude liigilise koosseisu kui kasvukohatüübi järgi. Kõik liigid eelistasid pesitseda okaspuul, eriti kuusel: tõenäoliselt pesa parema varjatuse tõttu. Pesapuu suurus oli tähtsam kui vanus, kuigi väheviljakates puistutes olid pesapuud nii vanemad kui ka väiksemad. Uuritud liikidest kannatavad majandusmetsades potentsiaalsete pesapuude vähesuse all kõige tõenäolisemalt kanakull, väike-konnakotkas ja hiireviu (Buteo buteo), kes asustasid alla 80-aastasi puistuid üldiselt vaid vanemate puude olemasolu korral. Seega saab säilikpuude abil nende kulliliste pesitsusvõimalusi oluliselt parandada. Koosluse tasemel ei seostunud valivus pesapaiga suhtes aga arvukusega, mis viitab sellele, et pesapaikade hulk ei olnud uuritud alal ja ajal metsakulliliste jaoks peamine limiteeriv tegur.
\end{abstract}

